\title{
Environmental pollution liability insurance in China: compulsory or voluntary?
}

\author{
Yan Feng ${ }^{\mathrm{a}, \mathrm{b}}$, Arthur P.J. Mol ${ }^{\mathrm{b}, * *}$, Yonglong $\mathrm{Lu}^{\mathrm{a}, *}$, Guizhen $\mathrm{He}^{\mathrm{a}}$, C.S.A. (Kris) van Koppen ${ }^{\mathrm{b}}$ \\ a State Key Laboratory of Urban and Regional Ecology, Research Center for Eco-Environmental Sciences, Chinese Academy of Science, 18 Shuangqing Road, \\ Beijing 100085, China \\ ${ }^{\mathrm{b}}$ Environmental Policy Group, Department of Social Sciences, Wageningen University, Hollandseweg 1, 6706 KN Wageningen, The Netherlands
}

\section{A R T I C L E I N F O}

\section{Article history:}

Received 10 June 2013

Received in revised form 6 January 2014

Accepted 11 February 2014

Available online 12 March 2014

\section{Keywords:}

Environmental pollution liability insurance

Compulsory liability insurance

Voluntary liability insurance

China

Environmental compensation system

Stakeholder analysis

\begin{abstract}
A B S T R A C T
China started the trial application of Environmental Pollution Liability Insurance in 2008, as part of a wider development of using market actors and market mechanisms in mitigating environmental pollution. Around the world and in China two main patterns of local pollution insurance practices can be identified: voluntary and compulsory pollution insurance promotion. In order to assess experiences from local pollution insurance practices in China and to contribute to the construction of a national pollution insurance policy in 2015, comparative case studies were carried out on voluntary (Chongqing) and compulsory (Wuxi, Jiangsu province) pollution insurance. Based on the analysis of pollution insurance products, differences in local policies, involved governance structures, and stakeholder attitudes, differences in pollution insurance market development between Chongqing and Wuxi are illustrated. The results show that in contemporary China, compulsory pollution insurance promotion helps local governments to quickly build a relatively mature system of pollution insurance. But it is too early to draw conclusions on the contribution of pollution insurance to environmental risk mitigation and pollution victim compensation.
\end{abstract}

(ㄷ) 2014 Elsevier Ltd. All rights reserved.

\section{Introduction}

Since the beginning of the 1980s, China has experienced a rapid economic growth with an average annual GDP increase of more than $9.8 \%$. In the same period, China witnessed a dramatic growth in numbers of environmental pollution accidents and environmental management problems increased, because of the abuse of natural resources and poor control of pollutants. In order to solve those environmental problems, China keeps searching for effective instruments for environmental management, and has experienced an "Ecological Modernization" since the 1990s (Mol, 2006; Zhang et al., 2007). With transformations toward a market-oriented growth model, and the growing openness to and integration in the global economy and polity, environmental governance in China shifted away from a traditional command-and-control model by increasingly involving private economic actors and market mechanisms in environmental protection (Mol, 2009). In this "Ecological Modernization" process, China's system of environmental

\footnotetext{
* Corresponding author. Tel.: +86 1062917903; fax: +86 1062918177.

** Corresponding author. Tel.: +31 317482495; fax: +31 317483990.

E-mail addresses: arthur.mol@wur.nl (A.P.J. Mol), yllu@rcees.ac.cn (Y. Lu).
}

governance is changing from a conventional command-and-control approach to more combined and comprehensive system. Many market-based instruments have been introduced in China, such as environmental subsidies, discharge fees, emission trading and most recently pollution insurance (or in full: Environmental Pollution Liability Insurance) (Mol and Carter, 2006).

Originated in industrialized countries in the 1960s, pollution insurance is an insurance that covers costs related to pollution, including the costs of brownfield restoration and cleanup, and liability costs for injuries and deaths caused by pollution (Stone, 2001). Pollution insurances have three main goals. First, pollution insurances protect individual companies from bankruptcy by spreading the risks and costs of environmental pollution of one company over a group of polluters (Freeman and Kunreuther, 1997). Second, pollution insurances also ensure that pollution victims can be compensated, even if the company that caused the environmental disaster goes bankrupt. In addition, pollution insurances mitigate environmental risks by incentivizing and rewarding polluters to invest in risk reduction and prevention measures through lower premiums (Freeman and Kunreuther, 2003). At present, pollution insurance is applied in many countries as an important instrument to control environmental risks and compensate the victims for their losses caused by environmental pollution, but is 
especially prevailing in the developed countries such as the United States, the United Kingdom, and Germany (Hollaender and Kaminsky, 2000). From international experiences, two main forms of pollution insurance can be identified: compulsory pollution insurance and voluntary pollution insurance. Compulsory pollution insurance mandatorily requires special industries to buy pollution insurance products, and was adopted for instance in the United States, Germany and Sweden (Bie, 2008; Ren and Shang, 2010). Voluntary pollution insurance, where industrial companies voluntarily decide to buy pollution insurance products, is applied in among others the United Kingdom and in France.

In dealing with growing environmental litigations (quarrels) on compensation and overburdened environmental state agencies, the Chinese government officially introduced pollution insurance as a new economic instrument in environmental governance to control environmental risk and compensate for environmental damage in 2006. In 2007, “The Guidelines on Environmental Pollution Liability Insurance" (The Guidelines) was issued by the Ministry of Environmental Protection (MEP) and the Insurance Regulation Committee (IRC), which declared the trial application of pollution insurance in local areas. By the end of 2008,8 provinces had started planning pollution insurance trial application, including Jiangsu, Chongqing, Hunan, Yunnan, Zhejiang and Shanghai. Up until the beginning of 2012, 14 cities and provinces have launched the trial application of pollution insurance. Based on experiences in pollution insurance implementation in these provinces, the government plans to build a national pollution insurance program in 2015.

Directed by national guidelines but faced with specific local circumstances, local governments in China developed their own strategies in the trial application of pollution insurance. Initial studies on China's pollution insurance found that local pollution insurance policies were developed with different motivations and preferences in different localities and reached mixed results (Feng et al., 2013). Reflecting global variation on pollution insurance, China has experimented locally with both compulsory and voluntary patterns at the local level. The former was adopted in, among others, Jiangsu and Hunan provinces, where local governments required polluters to buy pollution insurances. In Chongqing and Shenzhen, in contrast, are examples where local governments only stimulated and encouraged polluters in high-risk industries to buy pollution insurance. After application of pollution insurances during a trial phase for nearly four years (2008-2012), it is now possible to assess the two forms of pollution insurance in China. Hence, this paper will analyze, compare and evaluate the two modes of voluntary and compulsory pollution insurance in China. In doing so, we take a realist evaluation perspective, focusing on "what works for whom in what circumstances and in what respects, and how?" (Pawson and Tilley, 2004 P: 2), and using a casestudy methodology.

The next section outlines the research methodology and introduces two case studies. Subsequently we describe the different markets for pollution insurance in the two case studies (section 3) and analyze how local policies, governance structures and governance actors have resulted in different pollution insurance market developments (section 4 and 5).

\section{Research methodology: case studies on Chongqing and Wuxi}

Pollution insurance policies in China are only partly made by the national government. Since local conditions are of key importance in specifying national policies and promoting policy implementation, it is essential to study local developments and processes to understand pollution insurance policies. Since pollution insurance is a very recent phenomenon in China that has not yet spread widely, it is impossible to make a more quantitative analysis, and a case-study methodology is followed to obtain in-depth insights in how the two forms of pollution insurance work.

\subsection{Wuxi and Chongqing}

Wuxi and Chongqing were chosen as case-study sites for an indepth analysis and comparison of voluntary and compulsory pollution insurance promotion in China. Chongqing and Wuxi were selected as they have been pioneers in pollution insurance promotion since 2008. Chongqing and Wuxi are located in the poorer western and the richer eastern part of China, respectively (Fig 1). Wuxi was the first city in Jiangsu province that carried out pollution insurance trial application in 2009 with a typical format of compulsory pollution promotion. Chongqing started voluntary trial application of pollution insurance in 2009.

Located in the west of China, Chongqing became a municipality directly under the jurisdiction of the Chinese central government in 1997. Chongqing is an important basis for the West Development

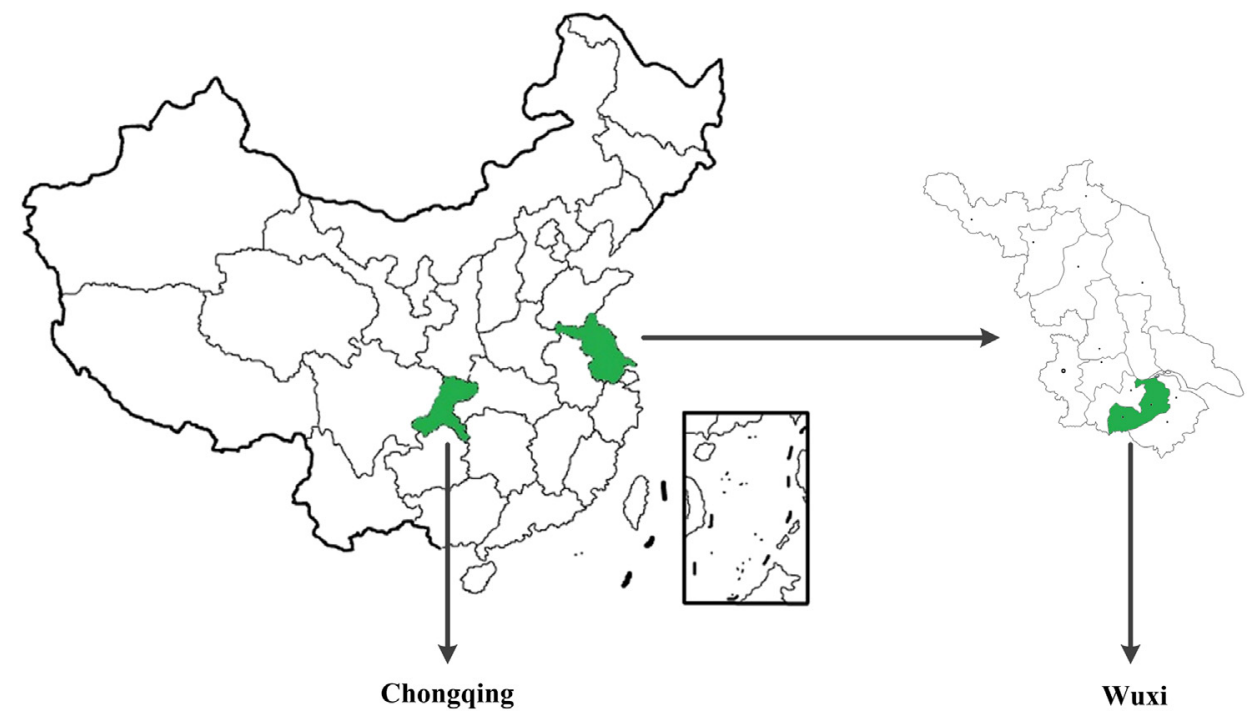

Fig. 1. The locations of Chongqing and Wuxi. 
Program, and has become one of the richest cities in the west of China. Chongqing covers an area of 82.4 thousand square kilometers, with a population around 29.2 million people in 2009 (Table 1), among which $61.7 \%$ was categorized as rural population. Chongqing forms the most important economic rim in the west of China, locating a concentration of nationally well-known enterprises in machinery, chemicals, medicine, and instrument industry. It is also an important financial center. In 2009, the total insurance premium income in Chongqing was 24.47 billion Yuan, which placed the city at the fifth position in China. It seems that Chongqing has a comparatively well-developed insurance market.

Jiangsu province is located in the east of China. With a population of 77.3 million, Jiangsu is one of the most crowded provinces with a high population density. In addition, Jiangsu is one of the richest provinces in China with a blooming industry. In 2009, the GDP of Jiangsu was 3445.7 billion Yuan, ranking 2nd of all 31 provinces, municipalities and autonomous regions in China. Wuxi is a modern and industrialized city located in the south of Jiangsu and famous for its manufacturing industry, biological and pharmaceutical industry, environmental protection industry, and micro-electronics. In 2011, the per capita GDP of Wuxi was highest among the cities in Jiangsu province (Table 1).

Both Chongqing and Wuxi play an important role as economic and industrial centers in their regions. However, as a city in the west, Chongqing is still much poorer than Wuxi. According to the 2009 Yearbook of China, the per capita GDP of Wuxi is nearly 3 times higher than that of Chongqing (Table 1). Also, Wuxi is more industrialized than Chongqing: the Gross Industrial Production contributed $53.11 \%$ to GDP, much higher than the share of Gross Industrial Production in Chongqing.

Both Chongqing and Wuxi are environmentally sensitive areas in China and in urgent need for environmental risk management. Chongqing, located in the upper reaches of Yangtze River, is an important part of the Three Gorges Reservoir Area. With rapid industrial development since the start of the West Development Program in 2000, Chongqing faces increasing environmental stress. Wuxi, near the major Taihu water system, has suffered heavy industrial pollution for a long time. In the absence of statistical data on environmental accidents in Wuxi city, we compare the moving average of environmental accidents per unit of industrial GDP in Chongqing city and Jiangsu province to show the trend of intensity of pollution incidents. In general, the intensity of environmental accidents increased in Chongqing till 2008, after which some improvement took place. In Jiangsu province environmental accidents decreased since 2003, and showed a recent increase in 2011 (Fig. 2). In Wuxi, no environmental accidents were reported in 2009, 2010 and 2011 (Yang, 2012).

\subsection{Research methods}

Field study on pollution insurance promotion was carried out in Chongqing and Wuxi in June and in December 2011, respectively. During field research, in-depth face-to-face interviews were held with local actors in pollution insurance. In Chongqing, we interviewed local Environmental Protection Bureau (EPB) officials (3), officials from the local Insurance Supervision Bureau (ISB) (2), and

Table 1

Economic indicators for Chongqing and Wuxi (2009).

\begin{tabular}{llllll}
\hline City & $\begin{array}{l}\text { Population } \\
\text { (million) }\end{array}$ & $\begin{array}{l}\text { Area } \\
\left(\mathrm{km}^{2}\right)\end{array}$ & $\begin{array}{l}\text { GDP } \\
\text { (billion } \\
\text { Yuan) }\end{array}$ & $\begin{array}{l}\text { Per capita } \\
\text { GDP } \\
\text { (thousand Yuan) }\end{array}$ & $\begin{array}{l}\text { Gross industrial } \\
\text { production/GDP } \\
(\%)\end{array}$ \\
\hline Chongqing & 29.2 & 82,402 & 1001.1 & 34.1 & 44.7 \\
Wuxi & 6.4 & 4787.6 & 688 & 108 & 53.1 \\
\hline
\end{tabular}

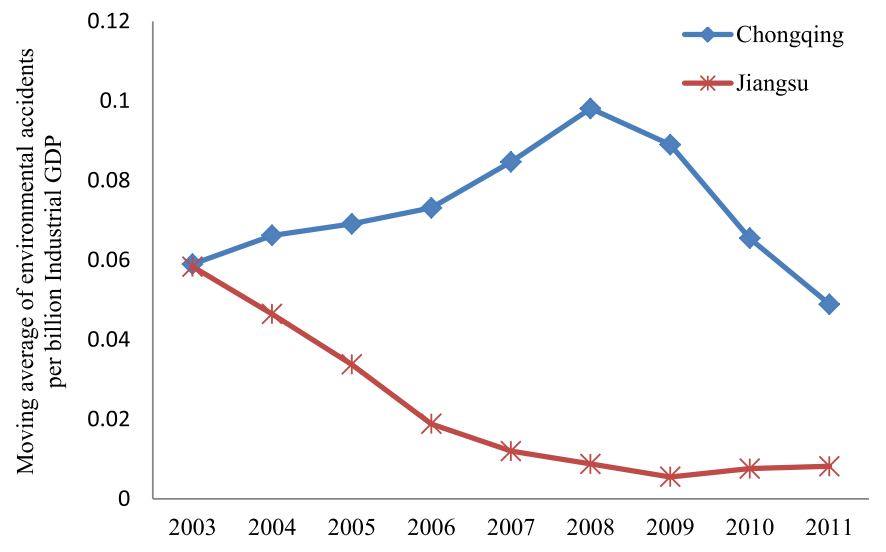

Fig. 2. Three-year moving average of environment accidents per billion Industrial GDP in Chongqing and Jiangsu, 2003-2011(China Statistical Yearbook, 2004-2012).

managers from four different insurance companies (10). In Wuxi, municipal government officials from different departments (5), officials from the provincial EPB (2), managers from two insurance companies (2), managers from two insurance broker companies (2) and experts from the insurance industry association (3) were interviewed. Polluting companies buying insurance products could not be interviewed, due to the fact that environmental pollution insurance issues were considered very sensitive by these companies and hence they refused interviews. Indirect information on behavior and attitudes of these polluters toward pollution insurances was collected through interviews with other actors and through document analysis (company reports and websites, media reports, governmental documents, secondary analysis of Chinese insurance literature). Because no pollution compensation cases had been reported in both cities, no interviews with victims could be carried out and assessing pollution insurance policy goal achievement with respect to victim compensation was not possible.

\section{Pollution insurance markets in Chongqing and Wuxi}

Both regions house a number of pollution insurance companies, who market their pollution insurance product. Because pollution insurance comes with large risks, in both Chongqing and Wuxi the government pushed the formation of so-called co-insurance organizations in local pollution insurance (Table 2). Through a coinsurance mechanism several insurance companies join together to share special risks in order to lower the risk covered by each insurance company. The co-insurance organizations develop uniform products and the main insurer usually is the main coordinator of pollution insurance business. This to some extent limits market competition among insurance companies. In both Chongqing and Wuxi, the People's Insurance Company (Group) of China (PICC) is the main insurer for pollution insurance. In Chongqing, the coinsurance organization is formed by 4 insurance companies, from which PICC has the largest share (about 30\%), while the other 3 companies have somewhat smaller shares. In practice, the pollution insurance business in Chongqing is divided according to administrative areas, so that each insurance company deals with pollution insurance selling to polluters located in their districts. The coinsurance organization in Wuxi is formed by five companies. In Wuxi, PICC takes the lead in pollution insurance business, including inviting experts to make risk assessment, negotiating with polluters on pollution contracts and arranging pollution insurance services. The other four insurers have significantly smaller shares in the pollution insurance market. 
Table 2

Pollution insurance products and insurers in Chongqing and Wuxi.

\begin{tabular}{|c|c|c|c|c|c|}
\hline & Insurers & $\begin{array}{l}\text { Premium } \\
\text { rate }(\%)\end{array}$ & $\begin{array}{l}\text { Basic risk } \\
\text { coverage }\end{array}$ & $\begin{array}{l}\text { Limited underwritten } \\
\text { value }\end{array}$ & $\begin{array}{l}\text { Retroactive } \\
\text { period }\end{array}$ \\
\hline Chongqing & $\begin{array}{l}\text { Co-insurance organizations: } \\
\text { PICC }\left(30 \%^{\mathrm{a}}\right) \text {, Ancheng }(24 \%) \text {, } \\
\text { Pingan }(23 \%) \text {, Huatai }(23 \%) \text {. }\end{array}$ & 2.6 & $\begin{array}{l}\text { (1) Direct loss of the third parties caused } \\
\text { by Environmental Pollution accident. } \\
\text { (2) Pollution clean-up cost. } \\
\text { (3) Legal cost. } \\
\text { (4) Additional risks: varied according to } \\
\text { negotiation }\end{array}$ & $\begin{array}{l}\text { Determination aggregate } \\
\text { limit of indemnity according to } \\
\text { negotiation. }\end{array}$ & 3 years \\
\hline Wuxi & $\begin{array}{l}\text { Co-insurance organizations: PICC (68\%), } \\
\text { Yangguang (11\%), } \\
\text { Pingan (9\%), Taipingyang (5\%), } \\
\text { ChanganZeren ( } 7 \%) \text {. }\end{array}$ & 2.0 & $\begin{array}{l}\text { (1) Direct loss of the third parties caused } \\
\text { by Environmental Pollution accident. } \\
\text { (2) Pollution clean-up cost. } \\
\text { (3) Legal cost. } \\
\text { (4) Additional risks: varied according to } \\
\text { negotiation }\end{array}$ & $\begin{array}{l}\text { Aggregate limit of indemnity: } \\
1,2,5,8,10 \text { million Yuan for } \\
\text { different industrial scales. }\end{array}$ & 3 years \\
\hline
\end{tabular}

\footnotetext{
${ }^{\text {a }}$ Share of each insurance company in co-insurance organization.
}

In order to compare the pollution insurance products in Chongqing and Wuxi, key characteristics in insurance product design were analyzed in this study, including the risk coverage, the premium rate, the underwritten value and the retroactive period. It was found that the pollution insurance product design in Chongqing and Wuxi was very similar. In both cities, the risk coverage of basic pollution insurance contracts are related to the loss caused by environmental pollution accidents, and do not include the environmental damage caused by gradual pollution release (Table 2). The insurers in both cities set a maximum limit for the underwritten value for pollution insurance, to lower the risk of having to pay huge compensation. In addition, the retroactive period was set to be 3 years among all insurers in both cities, which means that an insured company is covered for claims initiated during the contract period arising out of occurrences that took place in the three years before the effective date (Katzman, 1988). In general, because of the long term effects of environmental accidents (e.g. pollutants persist in the environment for a long time; the time of a pollution spill may precede the time of human exposure by many years; for some toxic chemicals, such as carcinogens, the time of human exposure may precede the manifestation of injuries by several decades) pollution insurance policies always set a long retroactive period. Currently, the retroactive period in China is much shorter than what is used in other countries. For example, in the United States, the retroactive period for chemical pollution is 30 years. The only difference in pollution insurance products between the two Chinese cities was the premium rate, which is set a little higher in Chongqing compared to Wuxi (Table 2). A likely reason for the higher premium rate in Chongqing is the relatively underdeveloped pollution insurance market in Chongqing compared to Wuxi (Table 3). Following the 'law of large numbers' in insurance companies, larger numbers of insurance holders result in smaller risks taken by insurers and in lower premium rates. Insurance companies in Chongqing assume huge risks of environmental accidents compensation for the few companies they have contracts with, and hence they set a higher premium rate to cover these risks. By the same token, a lower premium rate in Wuxi is more attractive to polluting companies, which further helped to expand the pollution insurance market and fortifies the 'law of large numbers'.

Hence, the pollution insurance markets in both cities have similar co-insurance mechanisms and similar designs of insurance products. However, regardless of these similarities, the information collected through interviews and through governmental and industry documents and data point at a very different development of the pollution insurance market in Chongqing and Wuxi (Table 3). Until July 2011, only 3 cases of pollution insurance contracts have been concluded in Chongqing, with a very limited amount of premium. In contrast, until the end of 2011, 688 polluters bought pollution insurance in Wuxi with a total premium of 14.2 million Yuan, covering about 763 million Yuan of capital. According to the local policies in Wuxi, 2000 companies are on the list of buying pollution insurances and signing contracts in the coming 5 years. In terms of the market size (companies insured and premiums), it can be concluded that Wuxi has a booming pollution insurance market while the pollution insurance market in Chongqing is only just starting (or even stagnating). In both cities, no pollution insurance compensation case has been officially reported. Hence, the function of pollution insurance in victim compensation has not been tested (yet). Since no data could be collected from the insured companies on pollution and improvement of environmental management, no conclusions can be drawn on whether pollution insurances mitigated environmental risks. However, the relatively mature pollution insurance market in Wuxi implies that insurance companies would be able to compensate for the loss, cover environmental clean-up costs and compensate the victims for any serious environmental accident of an insured company.

While a more definite assessment of the functioning of pollution insurances has to wait until further compensation cases are available, we can tentatively characterize the development of the pollution insurance market in Wuxi as successful. The question remains why the insurance market development in Chongqing is lagging largely behind that of Wuxi. With no major differences in the kind of insurance products offered and in the mechanism through which insurance companies are connected to polluting companies, can we explain the difference between mature and stagnating pollution insurance markets by looking at the pollution insurance policies (Section 4) and/or at the pollution insurance governance structure (Section 5$)$ ?

Table 3

The development of the pollution insurance market in Chongqing and Wuxi.

\begin{tabular}{|c|c|c|c|}
\hline & $\begin{array}{l}\text { Pollution } \\
\text { insurance deals }\end{array}$ & $\begin{array}{l}\text { Compensation } \\
\text { case }\end{array}$ & $\begin{array}{l}\text { Industries } \\
\text { insured }\end{array}$ \\
\hline Chongqing & $\begin{array}{l}\text { First case in } 2010 \text {. Till July 2011: } \\
3 \text { contracts, with } 7800 \text { Yuan } \\
\text { premium }\end{array}$ & Not yet & $\begin{array}{l}\text { Electroplating } \\
\text { industry, } \\
\text { medical waste } \\
\text { incinerator, } \\
\text { heavy metal } \\
\text { polluter. }\end{array}$ \\
\hline Wuxi & $\begin{array}{l}\text { First case in 2009. Till December } \\
2011 \text { : } 688 \text { contracts, with premium } \\
\text { of } 14.2 \text { million Yuan, covering } \\
763 \text { million Yuan. Plans to add } \\
400 \text { insured companies in } 2012 \text {. }\end{array}$ & $\begin{array}{l}\text { No official } \\
\text { case reported }\end{array}$ & $\begin{array}{l}\text { All kinds of } \\
\text { heavy } \\
\text { polluting } \\
\text { sectors }\end{array}$ \\
\hline
\end{tabular}


Table 4

The policy framework of pollution insurance in Chongqing and Wuxi.

\begin{tabular}{|c|c|c|}
\hline & Chongqing & Wuxi \\
\hline 2008 & & Start Shipping Insurance \\
\hline 2009 & $\begin{array}{l}\text { The Implementation Scheme of pollution } \\
\text { insurance in Chongqing }\end{array}$ & \\
\hline 2010 & The announcement of promoting liability & The Opinions on promoting pollution insurance in Jiangsu. \\
\hline & insurance in Chongqing & The implementation scheme of promoting the trial application of pollution insurance \\
\hline 2011 & $\begin{array}{l}\text { The regulations on pollution control of the } \\
\text { Three Gorge reservoir area (local legislation) }\end{array}$ & The administrative regulations on Taihu watershed (Decree of the State Council of China). \\
\hline
\end{tabular}

Table 5

The implementation documents for pollution insurance of Chongqing and Wuxi.

\begin{tabular}{|c|c|c|c|c|}
\hline Policy document & $\begin{array}{l}\text { Responsible } \\
\text { departments }\end{array}$ & Industrial scope of pollution insurance & $\begin{array}{l}\text { Preferential } \\
\text { policy }\end{array}$ & Punitive measures \\
\hline $\begin{array}{l}\text { The implementation } \\
\text { scheme for pollution } \\
\text { insurance in Chongqing }\end{array}$ & EPB and ISB & $\begin{array}{l}\text { Encourage companies in } 7 \text { sectors to } \\
\text { buy pollution insurance }\end{array}$ & No & No \\
\hline $\begin{array}{l}\text { The Implementation } \\
\text { Opinions of pollution } \\
\text { insurance in Wuxi }\end{array}$ & $\begin{array}{l}\text { Municipal } \\
\text { government }\end{array}$ & $\begin{array}{l}\text { Companies in } 3 \text { areas, and of } 24 \text { sectors } \\
\text { have to buy pollution insurance. } \\
\text { Other companies are encouraged to buy } \\
\text { pollution insurance. }\end{array}$ & $\begin{array}{l}\text { Subsidies from pollution } \\
\text { discharge fee. } \\
\text { Priority in application } \\
\text { pollution prevention funds }\end{array}$ & $\begin{array}{l}\text { Restrict new projects; } \\
\text { down one level in } \\
\text { company behavior } \\
\text { assessment. } \\
\text { No certification for } \\
\text { environmental protection; } \\
\text { Restriction on credit. }\end{array}$ \\
\hline
\end{tabular}

\section{Pollution insurance policies in Chongqing and Wuxi}

The policy framework for pollution insurance consists of two interwoven parts: the national policy and local policies. Since national policies on pollution insurance promotion are similar for Chongqing and Wuxi (Jiangsu), the local (interpretations and specifications of) policies are more influential in explaining differences in local practices.

Local pollution insurance promotion policies in Chongqing and Wuxi are summarized in Table 4. Under the direction of the national government, Chongqing issued "The implementation scheme for environmental pollution liability insurance" (The Implementation Scheme) in April 2009, which stipulated the principles, trial application scale, work targets and work stages of pollution insurance trial application. The Chongqing Environmental Protection Bureau (EPB) and the Chongqing Insurance Supervision Bureau (ISB) cooperated in issuing The Implementation Scheme as the main document for local policy making on pollution insurance promotion. Following The Implementation Scheme, Chongqing planned to select 35 companies in 7 industrial sectors to experiment with pollution insurance. Pushed by the EPB, in 2011 the Standing Committee of the (local) People's Congress (SCPC) in Chongqing passed "The regulations on pollution control of the Three Gorges Reservoir area", which further encouraged the companies in the Three Gorges reservoir area to buy pollution insurance. Neither the Implementation Scheme nor the Regulations has mandatory requirements for companies to have a pollution insurance, not strong measures to push companies to obtain a pollution insurance.

Trial application and implementation of pollution insurance in Wuxi involved provincial policies set by Jiangsu province. In 2008 Jiangsu started as the first province to promote pollution insurance through Shipping Insurance. ${ }^{1}$ In promoting pollution insurance trial

\footnotetext{
${ }^{1}$ In China, shipping insurance is seen as a type of environmental insurance as it insures the damage caused by ships to the water environment. In both local and central government documents, shipping insurance is included in the statistics of environmental insurance.
}

application throughout the province, the EPB, the ISB, and the Financial Department in Jiangsu province issued in 2010 "The Opinions on promoting Environmental Pollution Liability Insurance" (The Opinions), which announced the steps, principles, and detailed requirements for promoting pollution insurance. In this policy document, companies in several industrial sectors with high environmental risks, such as chemical industry, non-ferrous metal industry, and solid waste treatment, were selected and "forced" to buy pollution insurances. After two years of experiment with compulsory pollution insurance, the Wuxi municipal government issued in 2011 "The implementation opinions of environmental pollution liability insurance in Wuxi" (The Implementation Opinions), officially marking the beginning of mandatory pollution insurance all over Wuxi for specified industrial sectors. As part of Taihu watershed, Wuxi is influenced by the State Council decree "The administrative regulations on Taihu watershed", which also encouraged the companies in Taihu basin area to buy pollution insurance.

The most important local government documents that directly influenced trial application locally, the Implementation Scheme of pollution insurance in Chongqing and the Implementation Opinions of pollution insurance in Wuxi, are compared in Table 5. The key difference between the local policies in Chongqing and Wuxi is that the former only encourages companies in high-risk industries to voluntarily buy pollution insurance, while the latter considers pollution insurance compulsory for all industries in environmental sensitive areas and high-risk industrial sectors. Hence, the Implementation Opinions in Wuxi has preferential and restrictive measures to strengthen pollution insurance implementation, while the Implementation Scheme in Chongqing has no preferential and restrictive measures. Wuxi promotes pollution insurance with subsidies and funds, combined with command and control measures. For instance, companies from high-risk industrial sectors that did not buy pollution insurance in Wuxi cannot get their Environmental Impact Assessment approved for new construction or expansion projects, and will be degraded one level in company behavior assessment. In addition, their incompliance with the environmental regulations will be forwarded to banks to restrict 
credit support. Through these measures, the local government exerts considerable pressure on polluting companies to buy pollution insurances.

The Implementation Opinions in Wuxi is also more detailed with respect to the scales of companies involved, the implementation procedures and stakeholder responsibilities. Wuxi identified companies in 3 environmental sensitive regions and in 24 high-risk industrial sectors that have to be involved in compulsory pollution insurance. The former category consists of all industries with environmental pollution risks located in level 1 protection zones ${ }^{2}$ in Taihu lake basin, all polluting industries in level 2 drinking water source protection areas, and all industrial enterprises within $300 \mathrm{~m}$ of environmental sensitive areas such as hospitals, schools and large-scale residential areas. The latter category consists of enterprises in the industrial sectors with high environmental pollution risks, such as chemicals, sewage treatment, waste landfill, pharmacy, metallurgy, electroplating, leather, paper, cement, plastics, battery, thermal power, and garbage incineration power plants. The Implementation Opinions also stipulate the compensation fees and the kind of accidents covered by pollution insurances, as well as the implementation procedures. What is more, The Implementation Opinions mentions and stimulates the establishment of intermediary organizations in pollution insurance promotion and give them clear responsibilities (see below).

\section{Governing the insurance market}

Generally speaking, there are similarities in the governance structures and attitudes in pollution insurance promotion in local areas. The local EPB, under the direction of the MEP and the local municipal government, is responsible for industrial companies, while the Insurance Supervision Bureau (ISB), under the direction of Insurance Regulation Committee (IRC), is in charge of insurance businesses. Insurance companies and polluters are additional governance actors in the local pollution insurance market, where insurance contracts are made under the direction of governmental agencies. Third parties, including intermediary market actors and academic experts, can be involved in governing the pollution insurance market. $^{3}$ Irrespective of these general similarities, Chongqing and Wuxi differ in governance structures of and governance actor attitudes in pollution insurance promotion. These differences in structures and attitudes explain pollution insurance performance, but are at the same time also the result of past pollution insurance performance.

In Chongqing (Fig 3), the EPB is in charge of pollution insurance promotion. It introduced expert teams from the environmental protection industry association to gain technical support for policy making, risk classification and risk assessment. The municipal government (through ISB) pushed four insurance companies to form a co-insurance organization for the pollution insurance business. Although the co-insurance mechanism was established in 2009, according to our interviews the local pollution insurance companies had not really started cooperation on capacity building for risk classification, insurance service and insurance compensation by 2011.

\footnotetext{
2 According to the Water Pollution Prevention Law in China, the drinking water source zones are classified in different grades for environmental protection, based on their vulnerability to pollution. Level 1 protection zone is the most important and sensitive water source area.

${ }^{3}$ As no officially reported compensation case was found in both cities, and the victims do not play any role in policy making and only a limited one in policy implementation, the victims are not involved in the governance structure of the two case studies.
}

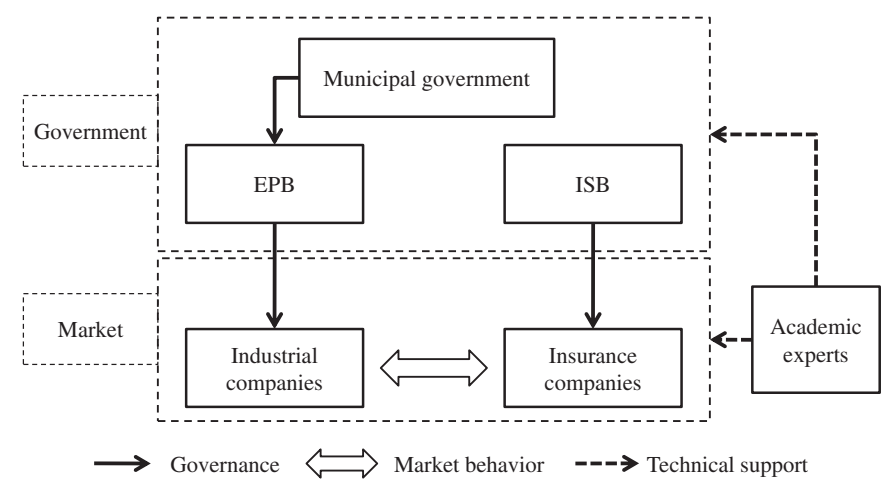

Fig. 3. The pollution insurance governance structure in Chongqing.

The attitudes of governmental authorities in Chongqing toward pollution insurance seemed to be rather cautious (Table 6). The Chongqing government was conservative in pollution insurance trial application. The insurance companies collaborated actively with government officials, as they saw pollution insurance as new business, be it with huge risks. The polluting industrial companies did hardly welcome pollution insurance and considered pollution insurance as unnecessary and additional economic costs. As a result, under conditions of voluntary pollution insurance polluters seldom bought pollution insurance.

In Wuxi (Fig 4), governmental support in pollution insurance trial application was much stronger than in Chongqing. Firstly, the EPB cooperated actively with other local government departments, such as the financial department, and pushed the local government toward compulsory pollution insurance policies. In addition, due to municipal government support, pollution insurance application was a target for local governments: all companies in the compulsory pollution insurance list were pushed to buy pollution insurance within five years. At the same time, the government commissioned an insurance broker company to assist in forming and implementing a co-insurance organization for pollution insurance through open tendering and designing pollution insurance products. Because of strong government support, the co-insurance organization, mainly controlled by PICC, structured the pollution insurance system swiftly. Assisted by local EPBs, the co-insurance organization cooperated with environmental consulting companies to engage environmental and engineering experts in assessing environmental risks of industrial companies. After risk assessment, a risk report including identification of key risks, risk level evaluation and risk control suggestions was sent to companies and local EPBs. This helped to rapidly exchange information between all stakeholders. Subsequently, local EPBs recommended the adoption of risk control measures to industrial companies, and the co-insurance organization started negotiations with industrial companies on pollution insurance contracts. After signing the contracts, the co-insurance organization supplied insured companies with pollution insurance services, such as risk control training. Mandatory pollution insurance created a mature pollution insurance market, with adequate information exchange and high total premium, which enabled the co-insurance organization to establish a well-functioning pollution insurance system with advanced risk assessments and pollution insurance services. Concerns are still related to huge upfront costs and the supervision of the rapid pollution insurance development. Overall, on the basis of interviews and document analysis, it can be concluded that Wuxi governmental agencies participated actively in construction of the pollution insurance market, and third parties played a more important role in pollution insurance trial application compared to 
Table 6

Actions and attitudes of governance actors in Chongqing.

\begin{tabular}{|c|c|c|c|}
\hline Chongqing & Actions & Attitudes & Perceptions of difficulties \\
\hline Gov. EPB and ISB & $\begin{array}{l}\text { - Issued guidelines } \\
\text { - Promoted establishment of co-insurance } \\
\text { organization } \\
\text { - Inspect the development of pollution } \\
\text { insurance } \\
\text { - Local legislation for pollution insurance }\end{array}$ & $\begin{array}{l}\text { Good policy for environmental } \\
\text { management exists. } \\
\text { - Cautious attitude: push pollution } \\
\text { insurance step by step } \\
\text { - No push via command and control. }\end{array}$ & $\begin{array}{l}\text { No national law for pollution insurance exist } \\
\text { - No national standard for risk assessment, or } \\
\text { loss identification. }\end{array}$ \\
\hline Insurance companies & $\begin{array}{l}\text { - Formed co-insurance organization on paper } \\
\text { - Design pollution insurance products }\end{array}$ & $\begin{array}{l}\text { Good policy for societal responsibility. } \\
\text { - Risk is too high and uncertain. } \\
\text { - Not beneficial in future. }\end{array}$ & $\begin{array}{l}\text { - No mandatory requirement of pollution insurance. } \\
\text { - Information insufficient. }\end{array}$ \\
\hline Polluting companies & $\begin{array}{l}\text { - Negotiation on pollution insurance contract. } \\
\text { - Buy pollution insurance product. }\end{array}$ & $\begin{array}{l}\text { Additional economic burden. } \\
\text { - Pollution insurance is not necessary. }\end{array}$ & - No financial support \\
\hline
\end{tabular}

Chongqing. More actors interacted more intensively with each other and pollution insurance was promoted more consistently in Wuxi than in Chongqing.

In Wuxi, the government took a strong preferential attitude (Table 7), thinking that only compulsory pollution insurance can work as an instrument for environmental risk control. Forced by the local government to buy pollution insurance, some industrial companies even felt that the government sold pollution insurance products to earn money. This more than incidental misunderstanding warns the government to be careful in pollution insurance market interventions.

There are commonly perceived difficulties in pollution insurance promotion in both cities: the absence of a national law, the weak technical support and the lack of funding. For local governments, the absence of a national law may disable local legislation on pollution insurance as local laws or policies may (be interpreted to) go against higher-level laws. For example, the policy that companies should buy pollution insurance is not in line with the national insurance law, and combining pollution insurance promotion with command-and-control measures from other environmental laws lacks national policy support. This creates uncertainties among local authorities promoting pollution insurance. Limited technology support was felt as an important problem for environmental risk assessment and environmental loss identification, a yet underdeveloped field in China. Up till now, the national government has not provided funding to local governments for pollution insurance trial application, nor has it issued policies on pollution insurance funding. As a result, local governments could hardly provide subsidies or funding to companies buying pollution insurances. In Wuxi, the government once used a part of the pollution discharge fee as subsidy for pollution insurance, but this

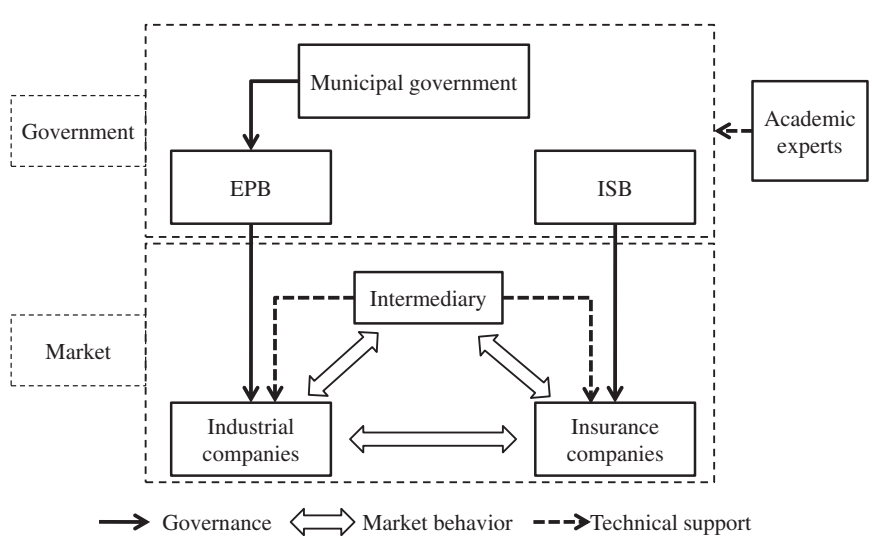

Fig. 4. The pollution insurance governance structure in Wuxi. idea was not allowed since it did not follow the "Regulations on collection and use of pollution discharge fee".

\section{Discussion and conclusions}

From the two case studies in Chongqing and Wuxi it becomes clear that in present China compulsory pollution insurance promotion results in a better implementation than voluntary pollution insurance. The distinction between rapid market development with compulsory pollution insurance promotion in Wuxi and a slow development of voluntary pollution insurance in Chongqing can also be observed in other pollution insurance trial regions in China. For example, until early 2012, compulsory pollution insurance in Hunan province resulted in 592 insured companies and the total premium of 20.34 million Yuan. While the voluntary pollution insurance in Shenzhen resulted in only 9 insured companies (Feng et al., 2013). Hence, with respect to pollution insurance market development compulsory pollution insurance works better than voluntary pollution insurance in China. But since the effects of the pollution insurance market on victim compensation and risk mitigation have not been 'tested' yet, it is possible that a fast developed pollution insurance market may not have the expected advantages for victim compensation and risk mitigation.

A number of reasons can explain why compulsory pollution insurance performs so much better than voluntary pollution insurance. Chongqing and Wuxi cases show that with the same difficulties of a lack of a national law, weak technical support and the lack of funding support, and with similar insurance products and insurers, compulsory pollution insurance outperforms due to strong support from governmental authorities. First, the environmental qualities are common goods. Many studies concerning how to alleviate the tragedy of common goods showed clearly that without stringent incentives and mandatory measures, the industry is very likely to choose the environmentally less friendly option (Chen et al., 2012; Szolnoki et al., 2012). Second, there is low willingness of polluters to pay voluntarily for an insurance as the risk of high costs related to environmental accidents and damage are still low in China. In the current primary phase of pollution insurance promotion, and a tradition that the government - if anybody - pays for environmental pollution damage in China, polluting company awareness in environmental social liabilities is weak. By the same token, national laws on environmental damage compensation and environmental litigation are hardly putting external pressure on polluters to compensate for environmental damage, which results in a very low willingness of industrial companies in China to voluntarily pay additional money for a pollution insurance. Third, pollution insurance is very new to China. The government, the insurance companies, and especially polluting 
Table 7

Actions and attitudes governance actors in Wuxi.

\begin{tabular}{|c|c|c|c|}
\hline Wuxi & Actions & Attitudes & Perceptions of the difficulties \\
\hline $\begin{array}{l}\text { Gov. EPB and other } \\
\text { departments }\end{array}$ & $\begin{array}{l}\text { Local legislation for pollution insurance. } \\
\text { Entrust insurance broker company with co-insurance } \\
\text { organization construction } \\
\text { - Publicize pollution insurance policy } \\
\text { - Help risk assessment of companies } \\
\text { - Make pollution insurance major work task of } \\
\text { governments at all levels. }\end{array}$ & $\begin{array}{l}\text { Pollution insurance is a good } \\
\text { environmental policy } \\
\text { - Entire government responsible } \\
\text { (not only EPB) } \\
\text { - Only compulsory policy works }\end{array}$ & $\begin{array}{l}\text { No national law for pollution } \\
\text { insurance } \\
\text { - No national fund for pollution } \\
\text { insurance } \\
\text { - Limited technology support }\end{array}$ \\
\hline $\begin{array}{l}\text { Insurance company PICC } \\
\text { (leading insurer) }\end{array}$ & $\begin{array}{l}\text { Engage expert teams to assess environmental } \\
\text { risks of companies. } \\
\text { - Negotiate pollution insurance contracts with companies } \\
\text { - Construct information exchange platform with government } \\
\text { and industrial companies. } \\
\text { - Follow-up service for companies } \\
\text { - Make public bidding for co-insurance organization } \\
\text { - Assist insurance companies with pollution insurance } \\
\text { products and services. }\end{array}$ & $\begin{array}{l}\text { Good policy for societal responsibility. } \\
\text { - Risk is too high and uncertain. } \\
\text { Not beneficial in the beginning } \\
\text { Help polluting companies to gain } \\
\text { fair interest. }\end{array}$ & $\begin{array}{l}\text { - Limited technology support. } \\
\text { - Weak awareness of pollution } \\
\text { insurance in polluting companies. } \\
\text { - No encouragement policy for } \\
\text { insurance companies. } \\
\text { - Huge upfront inputs. } \\
\text { - Limited technology support. } \\
\text { - Little supervision }\end{array}$ \\
\hline Polluting companies & $\begin{array}{l}\text { - Negotiate insurance contracts. } \\
\text { - Buy pollution insurance products. } \\
\text { - Cooperate with insurance companies on risk assessment } \\
\text { - Implement measures suggested by insurance companies. }\end{array}$ & $\begin{array}{l}\text { - Additional economic burden. } \\
\text { - Pollution insurance is unnecessary. } \\
\text { - Government has interest in selling } \\
\text { pollution insurance }\end{array}$ & $\begin{array}{l}\text { - Limited supporting funds. } \\
\text { a Premium is too high. }\end{array}$ \\
\hline
\end{tabular}

industrial companies have limited knowledge of this insurance. This leads to low levels of companies that are willing to buy an insurance (Ren and Shang, 2010), low numbers of insurance companies who actively promote these products, a not very competitive insurance market, and a somewhat hesitant attitude of governmental authorities. As a result, the demand of voluntary pollution insurance is too small, the development in the demand too slow and the competition too limited to shape a sizeable market that offers ‘value for money'. A large amount of premium with more competition enables a lower price and a better service. Finally, part of the explanation may also relate to economic development. Wuxi is richer than Chongqing, and in China richer regions often give relatively higher priority to environmental protection, while poorer regions narrowly focus on short-term economic development. This influences governmental priorities and attitudes toward industrial companies' incompliance.

In fact, the Chinese government is now realizing the better performance of compulsory insurance. On February 21, 2013, MEP and the IRC jointly promulgated The Guiding Opinions on Pilot Scheme for Compulsory Environmental Pollution Liability Insurance, which requires compulsory purchase of pollution liability insurance for companies with high environmental risks operating in China. Even in Chongqing city, one of our cases, the issuing of Notice of further work plan on the promotion of environmental pollution liability insurance in 2013 marked the change of local policies from voluntary to compulsory. This new trend of pollution insurance development may prove our research findings and implying that the Chinese government has shaped their idea of promoting compulsory pollution insurance, and prepared the pollution insurance system with establishment of the pollution prevention and control policies.

As a transitional country, the insurance market as well as the social awareness of environmental liabilities in China is not so welldeveloped as in developed countries, such as the United States and Germany. In addition, with the long history of planned economy and command-and-control administration, top-down measures in China are still considered to be more effective than bottom-up approaches (Schroeder, 2014). When applying a new marketbased instrument, foreign experiences may only be partially useful. As argued more often on ecological modernization processes in China (e.g. Zhang et al., 2007), involving market actors and making use of market mechanisms in environmental protection may follow a "Chinese way". This is in fact what we see in China's pollution insurance: combining market approaches with conventional command-and-control environmental governance proved to be effective in pollution insurance promotion. Hence, if the Chinese government implements its plan to establish a national pollution insurance system in 2015 (also to address growing complaints of unfair competition due to the absence of a level playing field in pollution insurance), a compulsory mode will be the most likely outcome.

\section{Acknowledgment}

This research was financed primarily by the International Science \& Technology Cooperation Program of China (2012DFA91150), Special Program for Basic Research of the Ministry of Science and Technology, China (2013FY111100), Key Project of Chinese Academy of Sciences (KZZD-EW-TZ-12), National Natural Science Foundation of China (71103175), Netherlands Royal Academy of Arts and Sciences (KNAW) and the Chinese Academy of Sciences (11CDP0280).

\section{References}

Bie, T., 2008. Environmental Pollution Liability Insurance in Foreign Countries, Qiu Shi. http://www.chinavalue.net/Media/Article.aspx?ArticleId=21601\&PageId=1 (in Chinese).

Chen, X., Szolnoki, A., Perc, M., 2012. Averting group failures in collective-risk social dilemmas. Europhys. Lett. 99, 68003.

Feng, Y., Arthur, M., Lu, Y., He, G., Koppen, K.v, 2013. Environmental Pollution Liability Insurance in China: In Need of Strong Government Backing. AMBIO, pp. 1-16.

Freeman, P.K., Kunreuther, H., 1997. Managing Environmental Risk through Insurance. Kluwer Academic Publishers.

Freeman, P.K., Kunreuther, H., 2003. Managing environmental risk through insurance. In: Henk Folmer, T.T. (Ed.), Yearbook of Environmental and Resource Economics. Edward Elgar Publishing Limited, pp. 159-189.

Hollaender, K., Kaminsky, M.A., 2000. The Past, Present, and Future of Environmental Insurance Including a Case Study of MTBE Litigation Environmenta Forensics, pp. 205-211.

Katzman, M.T., 1988. Pollution liability insurance and catastrophic environmental risk. J. Risk Insur. 55, 75-100.

Mol, A.P.J., 2006. Environment and modernity in transitional China: frontiers of ecological modernization. Dev. Change 37, 29-56.

Mol, A.P.J., Carter, N.T., 2006. China's environmental governance in transition. Environ. Polit. 15, 149-170.

Mol, A.P.J., 2009. Urban environmental governance innovations in China. Curr. Opin. Environ. Sustain. 1, 96-100. 
Pawson, R., Tilley, N., 2004. Realistic Evaluation. http://www.communitymatters. com.au/RE_chapter.pdf.

Ren, G., Shang, J., 2010. The Conditions of China's Environmental Liability Insurance System. IEEE.

Schroeder, P., 2014. Assessing effectiveness of governance approaches for sustainable consumption and production in China. J. Cleaner Prod. 63, 64-73.

Stone, A., 2001. Pollution insurance growing in popularity. Phila. Bus. J. http://www. bizjournals.com/philadelphia/stories/2001/11/05/focus4.html.
Szolnoki, A., Wang, Z., Perc, M., 2012. Wisdom of groups promotes cooperation in evolutionary social dilemmas. Sci. Rep. 2, 576.

Yang, H., 2012. Excellent performance of pollution insurance in Wuxi. Wuxi Dly. http://www.js.xinhuanet.com/wuxi/2012-02/12/content_24689763.htm Chinese).

Zhang, L., Mol, A.P.J., Sonnenfeld, D.A., 2007. The interpretation of ecological modernisation in China. Environ. Polit. 16, 659-668. 